\title{
Comparison Between Canopy Trees and Arboreal Lower Strata of Urban Semideciduous Seasonal Forest in Araguari - MG
}

\author{
João Paulo de Souza ${ }^{1 *}$, Glein Monteiro Araújoº ${ }^{2}$ Ivan Schiavini ${ }^{2}$ and Polyana Custódio \\ Duarte $^{2}$ \\ ${ }^{1}$ Programa de Pós-Graduação em Ecologia e Recursos Naturais; Universidade Federal de São Carlos; Bolsista \\ CNPq; joaopaulobio@hotmail.com;13565-905; São Carlos - SP - Brasil. ${ }^{2}$ Instituto de Biologia; Universidade \\ Federal de Uberlândia; Campus Umuarama; 38400-902; Uberlândia - MG - Brasil
}

\begin{abstract}
The present study intended to determine the phytosociological characteristics of the tree elements on the lower strata and the canopy of a semideciduous seasonal forest. The trees $(\geq 15 \mathrm{~cm}$ circumference at breast height) were sampled in 40 plots of $10 \mathrm{~m} \times 20 \mathrm{~m}$. The individuals in the lower strata ( $\geq 1 \mathrm{~m}$ up to $15 \mathrm{~cm}$ of circumference in the base of the stem) were sampled in plots of $10 \mathrm{~m} \times 10 \mathrm{~m}$. Licania apetala and Micrandra elata obtained the first and second places in the two strata. Among the species with the highest value of importance on the canopy, Alchornea glandulosa, Pimenta pseudocaryophyllus, Copaifera langsdorffii, Heisteria ovata and Didymopanax morototoni presented a ratio of less than one individual in the lower strata when compared to the canopy. However, there was a high floristic similarity between the lower strata and the canopy.
\end{abstract}

Key words: Semideciduous forest, lower strata, canopy

\section{INTRODUCTION}

The semideciduous seasonal forest has been more widely altered in all its occurrence area that comprehended part of Minas Gerais, Goiás, Mato Grosso do Sul and Bahia. In the remaining fragments, few present representative areas are preserved (Durigan et al., 2000). The use of these vegetation spots as public forests minimizes the action of factors such as fires, selective extraction and cattle invasion (Cielo Filho and Santin, 2002). According to Santin (1999), those areas are small and very isolated, due to the urbanization of their neighbourhood, as is the case of the forest in Araguari-MG. Several phytosociological studies on those forests were carried out in the States of São Paulo (Grombone et al., 1990; Bernacci and Leitão Filho, 1996; Dislich et al., 2001), and Minas Gerais (Araújo and Haridasan, 1997; Werneck et al., 2000a), with samples of individuals with a circumference at breast height $(\mathrm{CBH})>10 \mathrm{~cm}$. Surveys have been carried out using different methodologies, with a criterion of inclusion based on the height and on the circumference of the individual's stem (Felfili, 1997a; Durigan et al., 2000; Salimon and Negrelle, 2001). Felfili (1997a), in Distrito Federal, and Durigan et al. (2000) in the State of São Paulo, sampled all the individuals in a forest community. Salimon and Negrelle (2001) in Santa Catarina, used as inclusion criterion individuals with at least

${ }^{*}$ Author for correspondence 
one meter of height. Those studies, with wider samplings of the plant community allowed the classification of the same individuals in different strata (Durigan et al., 2000). However, in these surveys no standardized methodology was used, thus hindering the comparison of the results.

Researches in different strata of the forests can be useful for instantaneous responses about the diversity of species (Felfili, 1997a), and may also provide data for management plans and conservation of the forests. (Schlittler et al., 1995; Durigan et al., 2000; Barreira et al., 2002). Thus, the aim of this work was to compare the phytosociological structure of the canopy trees and lower strata (arboreal) in a semideciduous seasonal forest located in the urban area of the municipality of Araguari in the State of Minas Gerais, Brazil.

\section{MATERIAL AND METHODS}

Study area - The study was carried out at John Kennedy Forest ( $48^{\circ} 11^{\prime} \mathrm{W}$ and $18^{\circ} 38^{\prime} \mathrm{S}$ ), an urban semideciduous seasonal forest in the city of Araguari, Minas Gerais, Brazil. The area of 11.2ha of the forest was largely composed of a semideciduous seasonal forest $(73.21 \%$ of its total area), with arboreal individuals up to $25 \mathrm{~m}$ of height. The remaining of the area comprised trails, coops of plants and a small park for kids. Yet, some gaps were found in the forest, as a result of standing dead trees or tree falls (Araújo et al., 1997). According to Köppen's classification, the climate in the municipal district of Araguari is Cwa, with a relatively dry season in the winter and rains in the summer. The annual average temperature is $22^{\circ} \mathrm{C}$, and annual rainfall of $1500 \mathrm{~mm}$ (Rosa, 1992). The soil under the forest of Araguari was classified as an Acric Dark Red Latosol, with a franc-clayish texture. Due to the low availability of $\mathrm{K}, \mathrm{Ca}$ and $\mathrm{Mg}$, and to the high levels of exchangeable $\mathrm{Al}$, the soil presented a high-acidity (Araújo et al., 1997).

Sampling the Vegetation - The height was the criterion to differentiate the canopy species from those of the lower strata. In order to sample the canopy tree species, 40 plots of $10 \mathrm{~m} \times 20 \mathrm{~m}$ systematically located in the forest $(0.8 \mathrm{ha})$ were used. In each plot, all trees with a circumference of at least $15 \mathrm{~cm}$ at breast height $(1.30 \mathrm{~m})$ were sampled. For the lower strata sub-plots of $10 \mathrm{~m} \mathrm{x}$ $10 \mathrm{~m}$, within the $10 \mathrm{~m} \times 20 \mathrm{~m}$ plots were used. In those sub-plots, all individuals with at least one meter height and up to $15 \mathrm{~cm}$ circumference on the base of the stem were sampled. With the objective of determining which individuals would be included in the research, a 2-m bamboo stick was used to measure their height. The identification of the species was made in loco. Unknown species were collected for subsequent identification and deposited in the Herbarium Uberlandense (HUFUFederal University of Uberlândia). Identification was done by comparison with herbarium sheets and, specialists were also consulted. The classification system followed Cronquist (1988), except for Leguminosae which included Caesalpiniaceae, Fabaceae and Mimosaceae.

Data analysis - The phytosociological parameters (absolute and relative density, dominance, frequency, Shannon diversity index ( $\left.\mathrm{H}^{\prime}\right)$, and importance value index (IVI)) were obtained using the PREPARE and PARAMS applications of the FITOPAC I program (Sherpherd, 1995). The Sørensen index (Mueller-Dombois and Ellemberg, 1974) was used to calculate floristic similarity between the canopy trees and the arboreal lower strata. In order to establish the ratio between the two strata, the number of individuals in the arboreal lower strata sampled in a 0.4 ha area was divided by the individual of the same species at the canopy (0.8ha). For the comparison, the number of individuals of lower strata was projected for same area surveyed for canopy species.

\section{RESULTS}

In the phytosociological survey of the two arboreal strata, (lower and canopy), 4,396 individuals, distributed in 110 species, belonging to 46 families were sampled. In the lower strata, in 0.4ha, 3,218 individuals, belonging to 94 species, distributed in 43 families were sampled. In the canopy, 1,178 individuals, belonging to 90 species and 41 families were found in an area of 0.8ha (Table 1). The Shannon diversity index (H') was 3.3 nats/individual for the lower strata and 3.7 for the canopy, and the equability of Pielou (J') was 0.7 and 0.8 , respectively. The floristic similarity (Sørensen index) between the canopy and the lower strata was $78.26 \%$. Leguminosae, Rubiaceae and Myrtaceae were the families with a largest number of species in both the lower strata and the canopy, with 33 and $32 \%$ of the species total, respectively (Fig. 1). On the other hand, 24 
families in the lower strata and 25 in the canopy had only one species (Table 1).

The 19 most important species of the canopy and lower strata had 67.4 and $69.9 \%$, respectively of the total IVI. Among them, Licania apetala and Micrandra elata were ranked first and second in both strata. Among the 19 species with the highest IVI in the canopy, 13 had larger number of individuals in the lower strata. When compared with the canopy, Licania apetala (7.03), Micrandra elata (9.63), Inga vera (9.33), Aspidosperma discolor (9.80), Inga laurina
(11.60), Apuleia leiocarpa (12.63), and Micropholis venulosa (16.83) showed a proportion over seven times the number of individuals in the lower strata; and Astronium nelson-rosae (5.63) and Qualea jundiahy (5.64) had about five times more individuals in the lower strata. Among the species of high importance value in the canopy, Alchornea glandulosa (0.22), Pimenta pseudocaryophyllus (0.42), Copaifera langsdorffii (0.48), Heisteria ovata (0.48) and Didymopanax morototoni (0.95) had less individuals in the lower strata (Table 1).

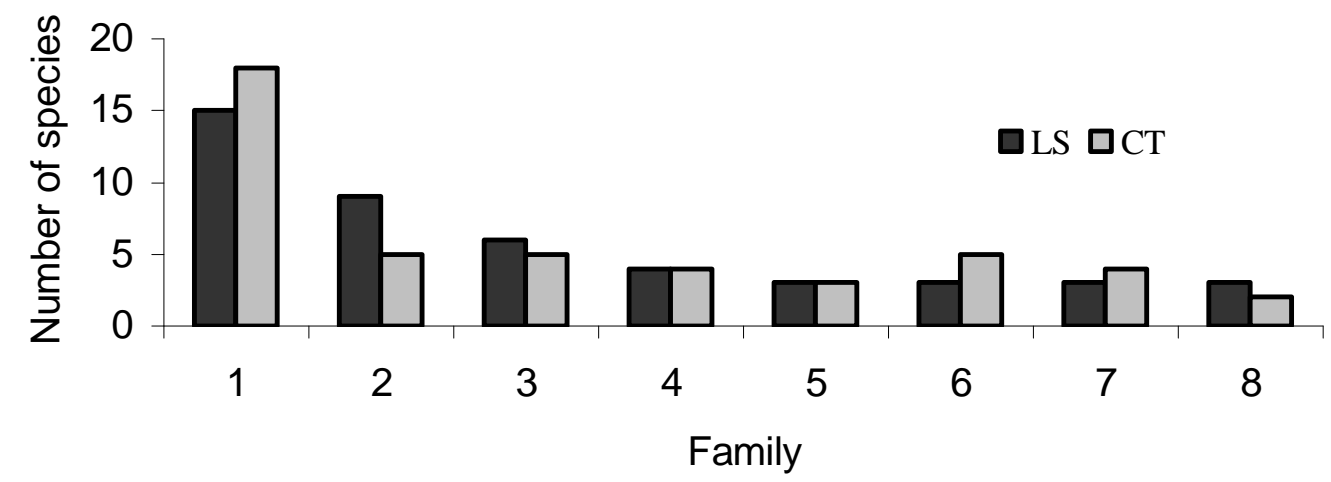

Figure 1 - Families with the largest numbers of species in the canopy trees (CT), and lower strata (LS), sampled in the semideciduous forest, Araguari, MG. 1 - Leguminosae, 2 - Myrtaceae, 3 Rubiaceae, 4 - Euphorbiaeae, 5 - Chrysobalanaceae, 6 - Annonaceae, 7 - Lauraceae, 8 Bignoniaceae.

Besides those species of a higher importance value index, a proportion of more than 13 times was registered in the lower strata than in the canopy in Myrcia rostrata (13.33), Protium heptaphyllum (18.46), Casearia grandiflora (22.67),
Siphoneugenia densiflora (37.2), Ocotea corymbosa (47.33) and Myrciaria sp. (122.0) (Table 1). The lower strata and canopy presented 20 and 17 exclusive species respectively (Table 1).

Table 1 - Species of the arboreal lower strata and canopy trees, ranked according to the IVI of the canopy trees, in the phytosociological sampling of the semideciduous forest, Araguari, Minas Gerais. $\mathrm{N}=$ number of individuals sampled; CT = Canopy trees, LS = Lower strata; IVI = importance value index; $\mathrm{P}=$ proportion of individuals in the lower strata in relation to canopy. * Number of individuals projected for the same area surveyed for canopy species.

\begin{tabular}{|c|c|c|c|c|c|c|}
\hline \multirow[t]{2}{*}{ Family } & \multirow[t]{2}{*}{ Species } & \multicolumn{2}{|c|}{$\mathbf{N}$} & \multicolumn{2}{|c|}{ IVI } & \multirow[t]{2}{*}{$\mathbf{P}$} \\
\hline & & CT & LS* & CT & $\mathbf{L S}$ & \\
\hline Chrysobalacaceae & Licania apetala (E. Mey.) Fritsch & 172 & 1210 & 34.07 & 36.74 & 7.03 \\
\hline Euphorbiaceae & Micrandra elata (Didr.) Müll. Arg. & 97 & 934 & 27.97 & 31.63 & 9.63 \\
\hline Leguminosae & Copaifera langsdorffii Desf. & 25 & 12 & 18.03 & 0.81 & 0.48 \\
\hline Euphorbiaceae & Alchornea glandulosa Poepp. \& Endl. & 73 & 16 & 12.12 & 1.42 & 0.22 \\
\hline Monimiaceae & Siparuna guianensis Aubl. & 61 & 82 & 9.87 & 4.62 & 1.34 \\
\hline
\end{tabular}


Cont. Table 1

\begin{tabular}{|c|c|c|c|c|c|c|}
\hline Araliaceae & Didymopanax morototoni (Aubl.) Decne. \& Planch. & 42 & 40 & 9.67 & 3.95 & 0.95 \\
\hline Annonaceae & Duguetia lanceolata A. St.-Hil. & 49 & 128 & 9.32 & 8.18 & 2.61 \\
\hline Anacardiaceae & Astronium nelson-rosae Santin & 32 & 180 & 8.75 & 7.95 & 5.63 \\
\hline Vochysiaceae & Qualea jundiahy Warm. & 33 & 186 & 8.64 & 9.42 & 5.64 \\
\hline Leguminosae & Inga laurina $(\mathrm{Sw}$.$) Willd.$ & 10 & 116 & 7.33 & 5.15 & 11.60 \\
\hline Rubiaceae & Amaioua intermedia Mart. & 43 & 92 & 7.16 & 6.57 & 2.14 \\
\hline Sapotaceae & Micropholis venulosa (Mart \& Eichler) Pierre & 24 & 404 & 6.46 & 16.10 & 16.83 \\
\hline Celastraceae & Maytenus sp. & 25 & 30 & 6.04 & 1.60 & 1.20 \\
\hline Leguminosae & Inga vera ssp. affinis (D.C.) T.D. Penn & 27 & 252 & 5.41 & 10.45 & 9.33 \\
\hline Leguminosae & Apuleia leiocarpa (Vogel) J.F. Macbr. & 16 & 202 & 5.35 & 8.51 & 12.63 \\
\hline Apocynaceae & Aspidosperma discolor A. DC. & 20 & 196 & 5.17 & 9.11 & 9.80 \\
\hline Olacaceae & Heisteria ovata Benth. & 21 & 10 & 5.16 & 0.69 & 0.48 \\
\hline Hippocrateaceae & Cheiloclinium cognatum (Miers) A.C. Sm. & 24 & 76 & 5.12 & 4.77 & 3.17 \\
\hline Myrtaceae & Pimenta pseudocaryophyllus (Gomes) Landrum & 24 & 10 & 5.04 & 0.41 & 0.42 \\
\hline Leguminosae & Hymenaea courbaril L. & 9 & 36 & 4.31 & 2.88 & 4.00 \\
\hline Rubiaceae & Ixora warmingii Müll. Arg. & 15 & 68 & 3.93 & 3.83 & 4.53 \\
\hline Anacardiaceae & Tapirira peckoltiana Engl. & 6 & 10 & 3.90 & 0.74 & 1.67 \\
\hline Meliaceae & Cabralea cangerana Saldanha & 22 & 12 & 3.85 & 1.16 & 0.55 \\
\hline Annonaceae & Annona cacans Warm. & 6 & - & 3.71 & - & 0.00 \\
\hline Myristicaceae & Virola sebifera Aubl. & 9 & 42 & 3.51 & 2.47 & 4.67 \\
\hline Burseraceae & Protium heptaphyllum (Aubl.) Marchand & 13 & 240 & 3.47 & 9.71 & 18.46 \\
\hline Chrysobalacaceae & Hirtella glandulosa Spreng. & 9 & 58 & 3.36 & 3.43 & 6.44 \\
\hline Rutaceae & Zanthoxylum rhoifolium Lam. & 11 & 14 & 3.18 & 0.93 & 1.27 \\
\hline Rubiaceae & Faramea cyanea Müll. Arg. & 15 & 114 & 3.06 & 5.77 & 7.60 \\
\hline Lauraceae & Ocotea spixiana (Nees) Mez & 4 & 46 & 2.80 & 2.89 & 11.50 \\
\hline Melastomataceae & Miconia sp. & 12 & - & 2.67 & - & 0.00 \\
\hline Combretaceae & Terminalia brasiliensis (Cambess. ex A. St.-Hil.) Eichler & 7 & 4 & 2.52 & 0.33 & 0.57 \\
\hline Vochysiaceae & Callisthene major Mart. & 3 & 4 & 2.44 & 0.35 & 1.33 \\
\hline Bignoniaceae & Jacaranda macrantha Cham. & 10 & 18 & 2.44 & 1.62 & 1.80 \\
\hline Asteraceae & Piptocarpha macropoda (DC.) Baker & 11 & 20 & 2.42 & 1.10 & 1.82 \\
\hline Chrysobalacaceae & Hirtella gracilipes (Hook. F.) Prance & 7 & 22 & 2.41 & 1.42 & 22.00 \\
\hline Bombacaceae & Chorisia speciosa A. St.-Hil. & 3 & 4 & 2.40 & 0.43 & 1.33 \\
\hline Boraginaceae & Cordia sellowiana Cham. & 9 & 16 & 2.01 & 1.32 & 1.78 \\
\hline Myrtaceae & Myrcia rostrata DC. & 9 & 120 & 2.00 & 6.83 & 13.33 \\
\hline Euphorbiaceae & Maprounea guianensis Aubl. & 9 & 10 & 1.84 & 0.86 & 1.11 \\
\hline Flacourtiaceae & Casearia grandiflora Cambess. & 9 & 204 & 1.83 & 8.96 & 22.67 \\
\hline Rubiaceae & Alibertia sessilis (Vell.) K. Schum. & 8 & 84 & 1.75 & 5.44 & 10.50 \\
\hline Lacistemataceae & Lacistema aggregatum (P.J. Bergius) Rusby & 8 & 48 & 1.74 & 3.48 & 6.00 \\
\hline Melastomataceae & Miconia sellowiana Naudin & 6 & - & 1.69 & - & 0.00 \\
\hline Piperaceae & Piper arboreum Aubl. & 11 & - & 1.66 & - & 0.00 \\
\hline Verbanaceae & Vitex polygama Cham. & 3 & 18 & 1.64 & 1.00 & 6.00 \\
\hline Leguminosae & Albizia polycephala (Benth.) Killip ex & 3 & 6 & 1.52 & 0.40 & 2.00 \\
\hline Myrtaceae & Siphoneugenia densiflora O. Berg. & 5 & 186 & 1.43 & 9.01 & 37.20 \\
\hline Meliaceae & Trichilia pallida $\mathrm{Sw}$. & 7 & 48 & 1.42 & 2.83 & 6.86 \\
\hline Styracaceae & Styrax acuminatus Pohl & 7 & 22 & 1.32 & 1.57 & 3.14 \\
\hline Myrtaceae & Eugenia florida DC. & 5 & 22 & 1.29 & 1.65 & 4.40 \\
\hline Elaeocarpaceae & Sloanea monospema Vell. & 4 & 14 & 1.23 & 1.35 & 3.50 \\
\hline Leguminosae & Platypodium elegans Vogel & 5 & 14 & 1.15 & 1.00 & 2.80 \\
\hline Sapotaceae & Pouteria torta (Mart.) Radlk & 4 & 4 & 1.13 & 0.31 & 1.00 \\
\hline Leguminosae & Machaerium sp. & 4 & 2 & 1.06 & 0.21 & 0.50 \\
\hline
\end{tabular}


Cont. Table 1

\begin{tabular}{|c|c|c|c|c|c|c|}
\hline Moraceae & $\begin{array}{l}\text { Sorocea bonplandii (Baiil.) W.C. Burger. Lanj. \& Wess. } \\
\text { Boer }\end{array}$ & 6 & 42 & 1.04 & 2.23 & 7.00 \\
\hline Moraceae & Ficus enormis (Mart. Ex Miq.) Mart. & 3 & 2 & 0.95 & 0.16 & 0.67 \\
\hline Opiliaceae & Agonandra brasiliensis Miers ex Benth. \& Hook. F. & 2 & 4 & 0.91 & 0.22 & 2.00 \\
\hline Leguminosae & Swartzia apetala Raddi & 4 & 34 & 0.87 & 2.01 & 8.50 \\
\hline Bignoniaceae & Tabebuia serratifolia (Vahl) G. Nicholson & 3 & 46 & 0.87 & 3.52 & 15.33 \\
\hline Leguminosae & $\begin{array}{l}\text { Senna macranthera (DC. ex Collad.) H.S. Irwin \& } \\
\text { Barneby }\end{array}$ & 6 & 8 & 0.76 & 0.62 & 1.33 \\
\hline Leguminosae & Cassia ferruginea (Schrader) Schrader ex DC. & 2 & 2 & 0.75 & 0.17 & 1.00 \\
\hline Annonaceae & Xylopia sericea A. St.-Hil. & 4 & 22 & 0.74 & 1.54 & 5.50 \\
\hline Lauraceae & Ocotea corymbosa (Meisn.) Mez & 3 & 142 & 0.71 & 6.84 & 47.33 \\
\hline Clusiaceae & Rheedia gardneriana Planch. \& Triana & 3 & 28 & 0.71 & 2.26 & 9.33 \\
\hline Annonaceae & Cardiopetalum calophyllum Schltdl. & 3 & 22 & 0.69 & 1.24 & 7.33 \\
\hline Apocynaceae & Aspidosperma cylindrocarpon Müll. & 1 & 5 & 0.64 & 0.77 & 5.00 \\
\hline Flacourtiaceae & Casearia gossypiosperma Briq. & 3 & - & 0.62 & - & 0.00 \\
\hline Lauraceae & Cryptocarya aschersoniana $\mathrm{Mez}$ & 2 & 14 & 0.60 & 1.03 & 7.00 \\
\hline Nyctaginaceae & Guapira cacerensis (Hoehne) Lund & 2 & 20 & 0.58 & 1.18 & 10.00 \\
\hline Lauraceae & Ocotea $\mathrm{sp}$ & 1 & - & 0.56 & - & 0.00 \\
\hline Leguminosae & Machaerium villosum Vogel & 1 & 10 & 0.52 & 0.59 & 10.00 \\
\hline Leguminosae & Swartzia myrtifolia Sm. & 2 & - & 0.52 & - & 0.00 \\
\hline Flacourtiaceae & Casearia sylvestris $\mathrm{Sw}$. & 2 & 16 & 0.52 & 1.00 & 8.00 \\
\hline Leguminosae & Sweetia fruticosa Spreng. & 1 & - & 0.50 & - & 0.00 \\
\hline Moraceae & Maclura tinctoria (L.) D. Don ex Steud. & 1 & - & 0.49 & - & 0.00 \\
\hline Melastomataceae & Mouriri apiranga Spruce ex Triana & 1 & - & 0.45 & - & 0.00 \\
\hline Myrtaceae & Myrciaria sp. & 1 & 122 & 0.45 & 7.91 & 122.0 \\
\hline Annonaceae & Annona sp. & 2 & - & 0.42 & - & 0.00 \\
\hline Proteaceae & Roupala brasiliensis Klotzsch & 1 & 16 & 0.38 & 0.91 & 16.00 \\
\hline Leguminosae & Ormosia arborea (Vell.) Harms & 2 & - & 0.37 & - & 0.00 \\
\hline Lecythidaceae & Cariniana estrellensis (Raddi) Kuntze & 2 & 14 & 0.35 & 0.99 & 7.00 \\
\hline Sapindaceae & Matayba guianensis Aubl. & 1 & 6 & 0.34 & 0.53 & 6.00 \\
\hline Euphorbiaceae & Pera glabrata (Schott) Poepp. ex Baill. & 1 & - & 0.32 & - & 0.00 \\
\hline Tiliaceae & Luehea grandiflora Mart. & 1 & - & 0.28 & - & 0.00 \\
\hline Leguminosae & Machaerium sp. 1 & 1 & - & 0.27 & - & 0.00 \\
\hline Leguminosae & Machaerium nyctitans (Vell.) Benth. & 1 & 2 & 0.27 & 0.27 & 2.00 \\
\hline Myrsinaceae & Rapanea lancifolia (Mart.) Mez & 1 & 2 & 0.26 & 0.18 & 2.00 \\
\hline Leguminosae & Bauhinia ungulata $\mathrm{L}$. & 1 & - & 0.26 & - & 0.00 \\
\hline Rubiaceae & Psychotria sp. & 1 & - & 0.26 & - & 0.00 \\
\hline Sapindaceae & Cupania vernalis Cambess. & - & 32 & - & 1.61 & 32.00 \\
\hline Polygalaceae & Bredemeyera floribunda Willd. & - & 24 & - & 1.21 & 24.00 \\
\hline Rubiaceae & Alibertia concolor (Cham.) K. Schum. & - & 16 & - & 1.11 & 16.00 \\
\hline Leguminosae & Machaerium aculeatum Raddi & - & 8 & - & 0.74 & 8.00 \\
\hline Bombacaceae & Eriotheca candolleana (K. Schum.) A. Robyns & - & 4 & - & 0.51 & 4.00 \\
\hline Rutaceae & Metrodorea pubescens A. St.- Hil. \& Tul. & - & 4 & - & 0.50 & 4.00 \\
\hline Myrtaceae & Gomidesia lindeliana $\mathrm{O}$. Berg. & - & 4 & - & 0.47 & 4.00 \\
\hline Myrtaceae & Myrcia coriacea (Vahl.) DC. & - & 4 & - & 0.41 & 4.00 \\
\hline Rubiaceae & Rudgea viburnoides (Cham.) Benth. & - & 4 & - & 0.39 & 4.00 \\
\hline Myrtaceae & Myrcia tomentosa (Aubl.) DC. & - & 4 & - & 0.34 & 4.00 \\
\hline Ulmaceae & Celtis iguanaea (Jacq.) Sarg. & - & 4 & - & 0.27 & 4.00 \\
\hline Nyctaginaceae & Guapira sp. & - & 2 & - & 0.26 & 2.00 \\
\hline Verbenaceae & Aegiphila sellowiana Cham. & - & 4 & - & 0.24 & 4.00 \\
\hline Rhamnaceae & Colubrina sp. & - & 4 & - & 0.23 & 4.00 \\
\hline Leguminosae & Sclerolobium paniculatum Vogel & - & 4 & - & 0.23 & 4.00 \\
\hline
\end{tabular}


Cont. Table 1

\begin{tabular}{|c|c|c|c|c|c|c|}
\hline Cecropiaceae & Cecropia pachystachya Trécul & - & 2 & - & 0.20 & 2.00 \\
\hline Euphorbiaceae & Margaritaria nobilis L. f. & - & 2 & - & 0.18 & 2.00 \\
\hline Bignoniaceae & Tabebuia sp. & - & 2 & - & 0.17 & 2.00 \\
\hline Symplocaceae & Symplocos sp. & - & 2 & - & 0.17 & 2.00 \\
\hline Myrtaceae & Calyptranthes lucida DC. & - & 2 & - & 0.15 & 2.00 \\
\hline
\end{tabular}

\section{DISCUSSION}

The forest of Araguari is an urban residual forest, administered by the municipality since 1988 (Araújo et al., 1997). In spite of the disturbance report (construction of paved trails, introduction of exotic species, isolation effect, among others), the forest presents physionomic and floristic aspects similar to other forest formations in the Triângulo Mineiro region. The height of the canopy trees, the complexity of the arboreal strata, and the richness of woody species determined herein are among the values found by Araújo and Haridasan (1997), Moreno and Schiavini (2001) in similar plant communities close to the area. There was a high floristic similarity between the lower strata and the canopy, showing that the trees in the forest were in their majority, regenerating in the area, and that the floristic composition of the community was not likely to undergo serious changes, except for those species with a small number of individuals in the lower strata, and those which, presented also a small population size in the canopy.

The Shannon diversity index for species of the lower strata and canopy were among the values (3.04 to 4.34) found in other surveys both for canopy (Araújo and Haridassan, 1997; Pinto and Oliveira-Filho, 1999; Dislich et al., 2001) and (1.75 to 2.01) with lower strata (Durigan et al., 2000; Salimon and Negrelle, 2001). The maximum diversity was found when all species were equally abundant (Magurran, 1988); in John Kennedy Forest there was a great predominance of some species, thus reducing the local diversity index.

Regarding the three families with the largest number of species found in the forest of Araguari, the Leguminosae presented the highest richness in Tropical forests. This could be a consequence of nitrogen transfer and retention, an important mechanism for the development and establishment of plants in this family (Faria et al., 1984). Myrtaceae and Rubiaceae occur with many species in the understorey (Durigan et al., 2000) and the canopy (Bernacci and Leitão Filho, 1996; Araújo and Haridasan, 1997), in semideciduous forests.
The number of individuals found in the phytosociological general sampling in the forest of Araguari was larger than in other studies developed in the region of Triângulo Mineiro. This was explained by the sampling of individuals $\geq 1$ meter of height, which determined the occurrence of a great number of young plants in the lower strata. This fact had already been observed by Felfili (1997a) in gallery forests, and Durigan et al. (2000) in semideciduous forests, with similar sampling criteria. Another fact observed was the occurrence of few species with numerous individuals. Most of the species had few individuals, a characteristic considered common in seasonal forests (Martins, 1991; Pagano et al., 1987).

The results showed that among the species with a higher importance value index in both strata, Licania apetala and Micrandra elata had the highest number of individuals. These species characterized the forest of Araguari, occupying the canopy with trees of dense crown, up to $25 \mathrm{~m}$ high. The occurrence of one or few species highly dominant in isolated forest fragments had already been observed by Leigh et al. (1993) and Araújo et al. (1997). In addition to the two mentioned species, Astronium nelson-rosae, Qualea jundiahy, Inga laurina, Micropholis venulosa, Inga vera ssp. affinis, Apuleia leiocarpa and Aspidosperma discolor had more individuals in the lower strata, and the proportion between this strata and the canopy was over five times. A. nelson-rosae, $I$. vera and $I$. laurina appear in phytosociological surveys of semideciduous forests, but commonly with a low number of individuals (Bernacci and Leitão Filho, 1996; Rodrigues et al., 1989; Lopes et al., 2002). $Q$. jundiahy, belonging to aluminumaccumulating Vochysiaceae (Haridasan and Araújo, 1988), occured with 14 and 32 individuals/ha in the canopy of semideciduous forests on aluminum-rich soils in the region of Triângulo Mineiro (Araújo and Haridasan, 1997; Araújo et al., 1997). M. venulosa was sampled with less than ten individuals in the arboreal strata of a gallery forest in DF (Felfili, 1994), and in a 
semideciduous forest in the south of Minas Gerais (Pinto and Oliveira-Filho, 1999). A. leiocarpa and A. discolor presented large populations on the canopy of forests in Distrito Federal (Felfili, 1997a), and in the region of Triângulo Mineiro (Araújo et al., 1997). According to Mantovani (2001), the occupation history, the natural dynamics and man's action processes could explain those variations. Considering the isolation of the fragment and the degree of human activity in the study area, those species seemed to be good competitors in the current stage of the forest.

Some of the most important species of the canopy, Copaifera langsdorffii, Didymopanax morototoni, Alchornea glandulosa, Heisteria ovata and Pimenta pseudocaryophyllus had a smaller number of individuals in the lower strata than in the canopy. Copaifera langsdorffii is a species with high dominance, but with few individuals in semideciuous forests in the region of Triângulo Mineiro (Araújo and Haridasan, 1997; Araújo et al., 1997), and in gallery forests in DF (Felfili, 1994). Felfili (1997b) suggests that many species of canopy do not follow the pattern of the "reverse-J", i.e., they do not present a high density of young individuals. This fact suggests low regeneration in recent years. Didymopanax morototoni and Alchornea glandulosa occur with many individuals in gaps in the forest of Araguari (Araújo et al., 1997), and present characteristics of pioneer species. Heisteria ovata presented also a few adult individuals in other forests in the South of Minas Gerais (Pinto and Oliveira-Filho, 1999; Lopes et al., 2002). Pimenta pseudocaryophyllus was mentioned as rare species by Werneck et al. (2000b) in deciduous forests in Minas Gerais. The number of plant species individuals can vary locally in response to the fragmentation and human activity (Whitmore, 1997). The opening of gaps (Laurence, 1997), absence of pollination, and seed dispersal (Viana et al., 1997), and the introduction of exotic species (Laurence, 1997), may be causing factors of the low recruitment for many species.

However, Protium heptaphyllum, Myrcia rostrata, Casearia grandiflora, Siphoneugenia densiflora, Ocotea corymbosa and Myrciaria sp. with a small importance value index and with few individuals in the canopy had more than 120 individuals in the lower strata. Protium heptaphyllum, which, according to Pinto and Oliveira-Filho (1999) was an initial secondary species, typical of humid environments in the area of Triângulo Mineiro, inhabited preferably gallery forests (Cardoso and Schiavini, 2002). Its presence in the forest of Araguari was likely to indicate possible changes in the humidity of the soil of the area. Myrcia rostrata and Casearia grandiflora, both pioneer species (Gandolfi et al., 1995) presented many individuals in areas of cerradão border (Cardoso and Schiavini, 2002) and semideciduous forests (Araújo and Haridasan, 1997) in Uberlândia, MG. Siphoneugenia densiflora, an canopy species with characteristics of secondary initial (tolerant to shade) (Tabarelli and Mantovani, 1997) was found with a low importance in a riparian forest in Itutinga (Van Den Berg and Oliveira-Filho, 2000). Ocotea corymbosa, species of canopy, a secondary initial (Gandolfi et al., 1995) was mentioned with a single individual in studies developed in São Paulo (Pagano et al., 1987; Rodrigues et al., 1989). Species with different life habits like the ones above mentioned seemed to be exploring, with many individuals in the lower strata, the several niches (gaps, borders of forest, areas covered with lianas, dense canopy) in the forest of Araguari. In the future, their representation in the canopy would depend on the forest dynamics and human activities occurring in the area.

Twenty species were exclusive of the lower strata, and 17 of the canopy. In their majority, these cited species previously do not exceed six individuals and they are, therefore, relatively rare. The changes in the structure of forest communities are caused by those rare species (Crow, 1980; Nascimento et al., 1999). Nascimento et al. (1999) mentioned that species with low population size and widely scattered in fragments could be more subject to local extinction. According to Cielo Filho and Santin (2002), species with few individuals, obligatory cross fertilization and without vectors for pollination and/or seed dispersal were likely to become extinct more easily. According to Turner et al. (1996), the extinction was due to the individuals death combined with the absence of recruitment. These species with few individuals were the most vulnerable to the fragmentation factors and human activities in the urban forest of Araguari, and required a close follow up of their responses to such processes.

Further studies and continuous observation would be necessary on both the structure and composition of the tree species so that the impacts of possible changes or damages to the forest, due to tourist 
visitation, as well as fragmentation effects could be effectively reduced.

\section{RESUMO}

$\mathrm{O}$ presente estudo pretendeu determinar as características fitossociológicas do estrato arbóreo superior e inferior, de uma floresta estacional semidecidual, visando à comparação entre estes estratos. As espécies do estrato superior $(\geq 15 \mathrm{~cm}$ circunferência à altura do peito) foram amostradas em 40 parcelas de $10 \mathrm{~m} \times 20 \mathrm{~m}$. As do estrato inferior $(\geq 1 \mathrm{~m}$ até $15 \mathrm{~cm}$ de circunferência na base do caule) em parcelas de $10 \mathrm{~m} \times 10 \mathrm{~m}$. Licania apetala e Micrandra elata obtiveram o primeiro e segundo lugares nos dois estratos. Entre as espécies de maior valor de importância do estrato superior Alchornea glandulosa, Pimenta pseudocaryophyllus, Copaifera langsdorffii, Heisteria ovata e Didymopanax morototoni, tiveram uma razão menor do que 1 indivíduo no estrato inferior em relação ao superior. Entretanto, houve uma alta similaridade florística entre $o$ estrato inferior e o superior.

\section{REFERENCES}

Araújo, G. M.; Guimarães, A. J. M. and Nakajima, J. M. (1997), Fitossociologia de um remanescente de mata mesófila semidecídua urbana, Bosque John Kennedy, Araguari, MG, Brasil. Revista Brasileira de Botânica, 20, 67-77.

Araújo, G. M. and Haridasan, M. (1997), Estrutura fitossociológica de duas matas mesófilas semidecíduas, em Uberlândia, Triângulo Mineiro. Naturalia, 22, 115-129.

Barreira, S.; Scolforo, J. R. S.; Botelho, S. A. and Mello, J. M. (2002), Estudo da estrutura da regeneração natural e da vegetação adulta de um cerrado senso stricto para fins de manejo florestal. Scientia Forestalis, 61, 64-78.

Bernacci, L. C. and Leitão Filho, H. F. (1996), Flora fanerogâmica da floresta da Fazenda São Vicente, Campinas, SP. Revista Brasileira de Botânica, 19, 149-164.

Cardoso, E. and Schiavini, I. (2002), Relação entre distribuição de espécies arbóreas e topografia em um gradiente florestal na Estação Ecológica do Panga (Uberlândia, MG). Revista Brasileira de Botânica, 25, 277-289.
Cielo Filho, R. and Santin, D. A. (2002), Estudo florístico e fitossociológico de um fragmento florestal urbano - Bosque dos Alemães, Campinas, SP. Revista Brasileira de Botânica, 25, 291-301.

Cronquist, A. (1988), The evolution and classification of flowering plants. New York: The New York Botanical Garden.

Crow, T. R. (1980), A rainforest chronicle: a 30-year record of change is structure and composition at $\mathrm{El}$ Verde, Puerto Rico. Biotropica, 12, 271-292.

Dislich, R.; Cersósimo, L. and Mantovani, W. (2001), Análise da estrutura de fragmentos florestais no Planalto Paulistano - SP. Revista Brasileira de Botânica, 24, 321-332.

Durigan, G.; Franco, G. A. D. C.; Saito, M. and Baitello, J. B. (2000), Estrutura e diversidade do componente arbóreo da floresta na Estação Ecológica dos Caetetus, Gália, SP. Revista Brasileira de Botânica, 23, 369-381.

Faria, S. M.; Franco, A. A.; Jesus, R. M.; Menandro, M. S.; Baitelo, J. B.; Mucci, E. S. F.; Dobereiner, J. and Sprenst, J. I. (1984), New nodulating legume trees from south-east Brazil. New phytologist, 98, 317-328.

Felfili, J. M. (1994), Floristic composition and phytosociology of the gallery forest alongside the Gama stream in Brasília, DF, Brazil. Revista Brasileira de Botânica, 17, 1-11.

Felfili, J. M. (1997a), Dynamics of the natural regeneration in the Gama Gallery forest in central Brazil. Forest Ecology and Management, 91, 235-245.

Felfili, J. M. (1997b), Diameter and height distributions in a gallery forest tree community and some of its main species in central Brazil over a six-year period (19851991). Revista Brasileira de Botânica, 20, 155-162.

Gandolfi, S.; Leitão Filho, H. F. and Bezerra, C. L. F. (1995), Levantamento florístico e caráter sucessional das espécies arbustivo-arbóreas de uma floresta mesófila semidecídua no Município de Guarulhos, SP. Revista Brasileira de Biologia, 55, 753-767.

Grombone, M. T.; Bernacci, L. C.; Meira-Neto, J. A. A.; Tamashiro, J. Y. and Leitão Filho, H. F. (1990), Estrutura fitossociológica da floresta semidecídua de altitude do Parque Municipal da Grota Funda (Atibaia - Estado de São Paulo). Acta Botanica Brasilica, 4, 47-64.

Haridasan, M. and Araújo, G. M. (1988), Aluminiumaccumulating species in two forest communities in the Cerrado region of central Brazil. Forest Ecology and Management, 24, 15-26.

Laurence, W. F. (1997), Hyper-disturbed parks: edge effects and the ecology of isolated rainforest reserves in tropical Australia. In: Laurence, W. F. and Bierregaard, R. O. (Eds.). Tropical forest remnants: ecology, management, and conservation of fragmented communities. Chicago: Chicago Press. pp. 71-83. 
Leigh, E. G.; Wright, S. J.; Herre, E. A. and Putz, F. E. (1993), The decline of tree diversity on newly isolated tropical islands: A test of a null hypothesis and some implication. Evolutionary Ecology, 7, 76-102.

Lopes, W. P.; Silva, A. F.; Souza, A. L. and MeiraNeto, J. A. A. (2002), Estrutura fitossociológica de um trecho de vegetação arbórea no Parque Estadual do Rio Doce - Minas Gerais, Brasil. Acta Botanica Brasilica, 16, 443-456.

Magurran, A. E. (1988), Ecological diversity and its measurements. London: Croom Helm.

Mantovani, W. (2001), A paisagem dinâmica. In: Leonel, C. (Ed.). Intervales. São Paulo: Fundação Florestal. pp. 81-91.

Martins, F. R. (1991), Estrutura de uma floresta mesófila. Série Teses. Campinas: Editora da Universidade Estadual de Campinas.

Moreno, M. I. C. and Schiavini, I. (2001), Relação entre vegetação e solo em um gradiente florestal na Estação Ecológica do Panga (MG). Revista Brasileira de Botânica, 24, 537-544.

Mueller-Dombois, D. and Ellenberg, H. (1974), Aims and methods of vegetation ecology. New York: John Wiley and Sons.

Nascimento, H. E. M.; Dias, A. S.; Tabanez, A. A. J. and Viana,V. M. (1999), Estrutura e dinâmica de populações arbóreas de um fragmento de floresta estacional semidecidual na região de Piracicaba, SP. Revista Brasileira de Biologia, 59, 329-342.

Pagano, S. N.; Leitão Filho, H. F. and Shepherd, G. J. (1987), Estudo fitossociológico em mata mesófila semidecídua no município de Rio Claro (Estado de São Paulo). Revista Brasileira de Botânica, 10, 49-61.

Pinto, J. R. R. and Oliveira-Filho, A. T. (1999), Perfil florístico e estrutura da comunidade arbórea de uma floresta de vale no Parque Nacional da Chapada dos Guimarães, Mato Grosso, Brasil. Revista Brasileira de Botânica, 22, 53-67.

Rodrigues, R. R.; Morellato, L. P. C.; Joly, C. A. and Leitão Filho, H. F. (1989), Estudo florístico e fitossociológico em um gradiente altitudinal de mata estacional mesófila semidecídua, na Serra do Japi, Jundiaí, SP. Revista Brasileira de Botânica, 12, 71-84.

Rosa, R. (1992), Caracterização Fisiográfica do Município de Araguari - MG. Sociedade and Natureza, 7/8, 53-75.

Salimon, C. I. and Negrelle, R. R. B. (2001), Natural Regeneration in a Quaternary Coastal Plain in Southern Brazilian Atlantic Rain Forest. Brazilian Archives of Biology and Technology, 44, 155-163.

Santin, D. A. (1999), A vegetação remanescente do município de Campinas (SP): mapeamento, caracterização fisionômica e florística, visando a conservação. $\mathrm{PhD}$ Tesis, Universidade Estadual de Campinas, Campinas, Brasil.
Shepherd, G. J. (1995), FITOPAC I: Manual do Usuário. Campinas: Universidade Estadual de Campinas.

Schlittler, F. H. M.; Marinis, G. and Cesar, O. (1995), Estudos fitossociológicos na floresta do Morro do Diabo (Pontal do Paranapanema, SP). Arquivos de Biologia e Tecnologia, 38, 217-234.

Tabarelli, M. and Mantovani, W. (1997), Colonização de clareiras naturais na floresta atlântica no sudeste do Brasil. Revista Brasileira de Botânica, 20, 57-66.

Turner, I. M.; Chua, K. S.; Ong, J.; Soong, B. and Tan, H. (1996), A century of plant species loss from na isolated fragment of lowland tropical rain forest. Conservation Biology, 10, 1229-1244.

Van Den Berg, E. and Oliveira-Filho A. T. (2000), Composição florística e estrutura fitossociológica de uma floresta ripária em Itutinga, MG, e comparação com outras áreas. Revista Brasileira de Botânica, 23, 231-253.

Viana, V. M.; Tabanez, A. A. J. and Batista, J. L. (1997), Dynamics and restoration of forest fragments in the Brazilian Atlantic moist forest. In: Laurence, W. F. and Bierregaard R. O. (Eds.). Tropical forest remnants: ecology, management, and conservation of fragmented communities. Chicago: Chicago Press. pp. 351-365.

Werneck, M. S.; Pedralli, G.; Koenig, R. and Giseke, L. F. (2000a), Florística e estrutura de três trechos de uma floresta semidecídua na Estação Ecológica do Tripuí, Ouro Preto, MG. Revista Brasileira de Botânica, 23, 97-106.

Werneck, M. S.; Franceschinelli, E. V. and TameirãoNeto, E. (2000b), Mudanças na florística e estrutura de uma floresta decídua durante um período de quatro anos (1994-1998), na região do Triângulo Mineiro, MG. Revista Brasileira de Botânica, 23, 401-413.

Whitmore, T. C. (1997), Tropical forest disturbance, disappearance, and species loss. In: Laurence, W. F. and Bierregaard R. O. (Eds.). Tropical forest remnants: ecology, management, and conservation of fragmented communities. Chicago: Chicago Press. pp. 3-12.

Received: November 09, 2004; Revised: August 05, 2005; Accepted: April 03, 2006. 